\title{
Penerapan Model Pembelajaran Problem Based Learning (PBL) untuk Meningkatkan Keterampilan Berpikir Kritis Peserta Didik pada Materi Usaha dan Energi Kelas X MIPA 4 SMAN 1 Gondang
}

\author{
Ariska Ribtyan Rosmasari*, Zainul Arifin Imam Supardi \\ Jurusan Fisika, Fakultas Matematika dan Ilmu Pengetahuan Alam, Universittas Negeri Surabaya \\ *Email: ariska.17030184099@mhs.unesa.ac.id
}

DOI: https://doi.org/10.33369/pendipa.5.3.472-478

\begin{abstract}
This study aimed to improve students' critical thinking skills through the application of the Problem Based Learning (PBL) learning model in the material of Work and energy material. This research used preexperimental research with one group pre-test design and post-test design. This research was conducted at SMAN 1 Gondang with one experimental class research design, namely class X MIPA 4. The method in this study used the normality test technique to determine the normal distribution category, the homogeneity test to determine the homogeneity data, the paired t-test to determine the comparison between pre-test and post-test scores, $n$-gain analysis to determine the improvement of students' critical thinking skills through pre-test and post-test scores, as well as quantitative descriptive to identify and describe the feasibility of learning with the PBL model. . The conclusion of this study is that learning with the PBL model can improve students' critical thinking skills with the moderate category and the learning implementation in the very good category.
\end{abstract}

Keywords: PBL learning model; Critical thinking skill; Work and Energy.

\begin{abstract}
ABSTRAK
Penelitian ini bertujuan untuk meningkatkan keterampilan berpikir kritis peserta didik melalui penerepan model pembelajaran Problem Based Learning (PBL) pada materi Usaha dan Energi. Penelitian ini menggunakan jenis penelitian pre-eksperimental dengan rancangan one group pre-test dan post-test design. Penelitian ini dilakukan di SMAN 1 Gondang dengan desain penelitian satu kelas eksperimen yaitu kelas X MIPA 4. Metode pada penelitian ini menggunakan teknik uji normalitas untuk mengetahui kategori pendistribusian normal, uji homogenitas untuk mengetahui kehomogenan data, uji t-berpasangan untuk mengetahui perbandingan antara nilai pre-test dan nilai post-test, analisis $n$-gain untuk mengetahui peningkatan keterampilan berpikir kritis peserta didik melalui nilai pre-test dan nilai post-test, serta deskripitif kuantitatif untuk mengetahui serta mendeskripsikan keterlaksanaan pembelajaran dengan model PBL. Kesimpulan dari penelitian ini adalah pembelajaran dengan model PBL dapat meningkatkan keterampilan berpikir kritis peserta didik dengan kategori sedang serta keterlaksanaan pembelajaran dengan kategori sangat baik.
\end{abstract}

Kata kunci: Model pembelajaran PBL; Keterampilan berpikir kritis; Usaha dan Energi.

\section{PENDAHULUAN}

Pendidikan yang baik adalah pendidikan yang memahami materi yang berkaitan dengan kehidupan sehari-hari melalui penerapan model pembelajaran inovatif (Hidayani, 2017). Selain itu, dalam proses pembelajran fisika, peserta didik akan berusaha keras untuk memahami dampak dari ilmu pengetahuan alam terhadap kehidupan dan pemecahan masalah. Dalam proses pembelajaran, peserta didik biasanya memegang posisi wadah kosong yang berisi berbagai macam ilmu. Hal ini dapat menghambat kemampuan berpikir peserta didik. Karena itu 
hanya akan menjadikan peserta didik sebagai objek dalam proses pembelajaran (Ramadha, 2016). Pada proses pembelajaran seharusnya selalu menerapkan keterampilan berpikir untuk menciptakan pembelajaran yang baik. Keterampilan berpikir penting yang perlu dipelajari adalah keterampilan pemikiran lain yang lebih tinggi, pemikiran kompleks, serta pemikiran kritis (Ramadha, 2016)

Fisika merupakan salah satu ilmu pengetahuan alam yang mempelajari mengenai hukum alam, tingkah laku serta hubungannya dengan fenomena fisika pada kehidupan seharihari. Pada saat ini di sekolah peserta didik dituntut untuk memiliki prestasi yang tinggi terlebih di era pandemi, dengan sistem pembelajaran daring yang mana peserta didik dengan guru tidak dapat bertatap muka secara langsung, serta pendidikan karakter yang sesuai dengan Kurikulum K13.

Selain memberikan tema, guru juga dituntut untuk menyelenggarakan pendidikan karakter. Peserta didik juga dituntut untuk berkonsentrasi belajar dan belajar secara metodis agar tercipta peserta didik yang kreatif, produktif dan inovatif, bahkan dalam konteks pandemi. Di abad 21 ini, peserta didik harus memiliki keteranpilan 4C. Termasuk pemikiran kritis dan pemecahan masalah, kreativitas dan inovasi, kolaborasi dan komukasi. Keterampilan tersebut masih berkaitan dengan empat pilar kehidupan, yaitu belajar melakukan sesuatu, belajar menjadi pribadi, dan belajar hidup bersama. Keempat prinsip tersebut memiliki keterampilan khusus yang berkaitan erat dengan kegiatan pembelajaran, salah satunya adalah keterampilan berpikir kritis (Trilling, 2009).

Menurut Ibrahim dan Nur, pembelajaran berbasis masalah merupakan model pembelajaran inovatif yang dirancang untuk memungkinkan peserta didik memperoleh pengetahuan penting sehingga dapat menyelesaikan masalah dengan baik, terutama dalam kehidupan sehari-hari. Hal ini merupakan bentuk belajar mandiri dan kemampuan belajar. Berpartisipasi dalam pekerjaan kelompok atau tim (Ibrahim, 2000).

Pembelajaran dengan menggunakan model Problem Based Learning merupakan salah satu inovasi model pembelajaran. Model Problem Based Learning merupakan model pembelajaran dengan mengoptimalkan kemampuan berpikir peserta didik melalui kegiatan belajar secara berkelompok atau tim yang sistematis, sehingga peserta didik dapat mengasah, memberdayakan, mengembangkan serta menguji kemampuan berpikirnya secara sistematis atau berkesinambungan (Rusman, 2013).

Menurut Ardeninyansah \& Rosnawati, model pembelajaran PBL merupakan model pembelajaran dengan peserta didik sebagai pusat dalam kegiatan pembelajaran (student-centered). Model PBL merupakan model dengan teknis memberikan permasalahan langsung atau nyata yang terjadi pada kehidupan sehari-hari untuk dijadikan sebagai bahan dalam menganalisis sehingga menemukan sebuah solusi dalam permasalahan tersebut. Setelah menemukan solusi tersebut, selanjutnya peserta didik merancang serta membuat sebuah produk yang kemudian ditampilkan di depan kelas. Selama kegiatan pembelajaran berlangsung, guru berperan sebagai fasilitator untuk membimbing diskusi kelompok namun tidak terlibat secara langsung dalam kegiatan pengamatan atau analisis (Ardeninyansah, 2018).

Pada model pembelajaran PBL mengangkat permasalahan yang terjadi pada kehidupan sehari-hari. Permasalahan tersebut dapat berasal dari guru atau peserta didik itu sendiri (Arends, 2012). Sehingga, model pembelajaran Problem Based Learning efektif digunakan dalam mengembangkan keinginan peserta didik untuk meningkatan keterampilan berpikir (Santrok, 2014). Menurut John R. Mergendoller dan John Lamer, model pembelajaran PBL merupakan sebuah model pembelajaran yang berbasis proyek tertentu sebagai media peserta didik untuk menyalurkan kemampuannya. Ketika merancang suatu proyek diperlukan standar tertentu yang disebut juga dengan Gold Standart PBL atau Satandar Emas PBL (Mergendoller, 2015).

Berpikir kritis merupakan berpikir langsung kepada fokus yang akan dituju, hal tersebut disebut juga dengan direct thinking. Berpikir kritis menjadikan seseorang mampu menentukan tujuan, keterkaitan atau hubungan antara suatu hal, serta mempertimbangkan keputusan yang akan diambil untuk menentukan suatu kebenaran 
dan pendidikan. Selain itu berpikir krtis berfokus pada proses kognitif analitis dan evaluatif (Arends, 2012). Keefektifan dalam berpikir kritis dipengaruhi oleh keterampilan peserta didik dalam memilih dan menentukan keakuratan suatu informasi beserta argumennya. Berpikir kritis juga diperlukan sikap berorientasi untuk menemukan suatu pengetahuan dengan kebenaran (Arends, 2012). Maka dari itu diperlukan karakteristik dari keterampilan berpikir kritis.

Menurut Facione, keterampilan berpikir kritis seseorang dapat dilihat melalui bagaimana cara seseorang berpikir serta mengaplikasikan pemikirannya secara nyata. Selain itu, berpikir kritis memiliki indikator, antara lain analisis, interpretasi, inferensi, eksplanasi, evaluasi, dan regulasi diri. Namun, pada indikator eksplanasi dan regulasi diri sulit diukur menggunakan tes, sehingga penelitian ini hanya menggunakan empat indikator (Facione, 2015).

Tabel 1. Indikator Keterampilan Berpikir Kritis

\begin{tabular}{|c|c|c|}
\hline $\begin{array}{c}\text { Keterampil } \\
\text { an Berpikir } \\
\text { Kritis } \\
\end{array}$ & $\begin{array}{c}\text { Sub- } \\
\text { keterampilan } \\
\text { Berpikir Kritis }\end{array}$ & Aspek \\
\hline Analisis & $\begin{array}{l}\text { 1. Memeriksa } \\
\text { gagasan } \\
\text { 2. Menganalisi } \\
\text { s argumen } \\
\text { 3. Mendeteksi } \\
\text { argument }\end{array}$ & $\begin{array}{l}\text { 1. Mengidentifik } \\
\text { asi masalah } \\
\text { atau isu sosial } \\
\text { 2. Memberikan } \\
\text { pendapat } \\
\text { disertai alasan } \\
\text { yang } \\
\text { mendukung } \\
\text { 3. Menghubungk } \\
\text { an pendapat } \\
\text { dengan } \\
\text { masalah }\end{array}$ \\
\hline Interpretasi & $\begin{array}{l}\text { 1. Mengkateg } \\
\text { orisasikan } \\
\text { 2. Mengubah } \\
\text { signifikans } \\
\text { i } \\
\text { 3. Memperjel } \\
\text { as makna }\end{array}$ & $\begin{array}{l}\text { 1. Mengklasifika } \\
\text { sikan data, } \\
\text { temuan atau } \\
\text { opini. } \\
\text { 2. Menafsirkan } \\
\text { data yang } \\
\text { disajikan. } \\
\text { 3. Menyatakan } \\
\text { kembali suatu } \\
\text { data dalam } \\
\text { ungkapan } \\
\text { yang berbeda }\end{array}$ \\
\hline
\end{tabular}

\begin{tabular}{|c|c|c|}
\hline & & $\begin{array}{l}\text { dan didukung } \\
\text { dengan contoh } \\
\text { nyata. }\end{array}$ \\
\hline Inferensi & 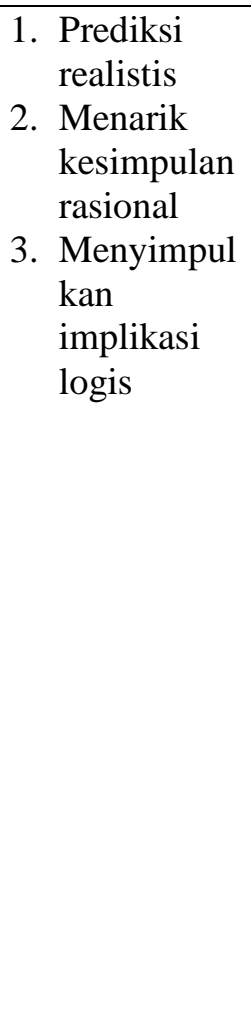 & $\begin{array}{l}\text { 1. Menilai } \\
\text { informasi } \\
\text { untuk } \\
\text { menentukan } \\
\text { pendapat } \\
\text { tertentu lebih } \\
\text { atau kurang } \\
\text { masuk akal. } \\
\text { 2. Menimbang } \\
\text { kesulitan dan } \\
\text { manfaat yang } \\
\text { dihasilkan dari } \\
\text { pengambilan } \\
\text { keputusan. } \\
\text { 3. Menyimpulka } \\
\text { n hasil untuk } \\
\text { mengkonfirma } \\
\text { si atau } \\
\text { menolak } \\
\text { hipotesis } \\
\text { berdasarkan } \\
\text { data yang } \\
\text { relevan. }\end{array}$ \\
\hline Evaluasi & $\begin{array}{l}\text { 1. Penilaian } \\
\text { klaim } \\
\text { 2. Penilaian } \\
\text { argumen }\end{array}$ & $\begin{array}{l}\text { 1. Menentukan } \\
\text { apakah } \\
\text { pernyataan } \\
\text { tertentu } \\
\text { mungkin } \\
\text { benar atau } \\
\text { salah } \\
\text { berdasarkan } \\
\text { apa yang } \\
\text { diketahui. } \\
\text { 2. Menilai } \\
\text { relevansi } \\
\text { argument pada } \\
\text { situasi yang } \\
\text { dihadapi }\end{array}$ \\
\hline
\end{tabular}

Kriteria pada berpikir kritis antara lain, relevansi, sumber yang kredibel, logika yang konsisten, keakuratan fakta, teliti, serta mempertimbangkan secara matang agar mampu menyimpulkan berdasarkan hubungan antara fakta dan data. Menurut Facione, keterampilan berpikir kritis seseorang dapat dilihat melalui 
bagaimana cara seseorang berpikir serta mengaplikasikan pemikirannya secara nyata. Selain itu, berpikir kritis memiliki indikator, antara lain analisis, interpretasi, inferensi, eksplanasi, evaluasi, dan regulasi diri. Namun, pada indikator ekplanasi dan regulasi diri sulit diukur menggunakan tes, sehingga penelitian ini hanya menggunakan empat indikator (Facione, 2015).

Berdasarkan uraian di atas, maka dalam penelitian ini diterapkan model pembelajaran PBL untuk meningkatkan keterampilan berpikir kritis peserta didik.

\section{METODE PENELITIAN}

Pada penelitian ini yang digunakan adalah metode atau jenis penelitian pre-experiental dengan one group pre-test post-test design (Sugiyono, 2015). Penggunaan metode ini untuk mengetahui pengaruh penerapan model PBL terhadap keterampilan berpikir kritis peserta didik pada materi usaha dan energi kelas $\mathrm{X}$ MIPA 4 SMAN 1 Gondang. Penelitian ini menggunakan sampel dengan teknik simple random sampling, yaitu peluang yang diberikan bersifat sama selanjutnya untuk pemilihan dilakukan secara acak. Skema rancangan penelitian ini dapat dilihat pada Tabel 1 berikut:

Tabel 2. Skema rancangan penelitian

\begin{tabular}{cccc}
\hline $\begin{array}{c}\text { No. Urut } \\
\text { Peserta } \\
\text { Didik }\end{array}$ & Pre-test & Perlakuan & Post-test \\
\hline X MIPA 4 & $\mathrm{O}_{1}$ & $\mathrm{X}$ & $\mathrm{O}_{2}$ \\
\hline \multicolumn{4}{c}{ (Sugiyono, 2015) } \\
Keterangan : \\
$\mathrm{O}_{1} \quad \begin{array}{l}\text { :hasil pre-test sebelum diberi perlakuan } \\
\text { (penerapan model PBL) }\end{array}$ \\
$\mathrm{O}_{2} \quad \begin{array}{l}\text { :hasil post-test sesudah diberi perlakuan } \\
\text { (penerapan model PBL) }\end{array}$ \\
$\mathrm{X}$ & $\begin{array}{l}\text { :perlakuan dengan penerapan } \\
\text { pembelajaran PBL }\end{array}$ & model \\
&
\end{tabular}

Pengambilan data pada penelitian ini diambil pada bulan Maret tahun 2021, tepatnya pada tahun ajaran genap 2020/2021. Selain hasil dari pre-test dan post-test ada data mengenai keterlaksanaan model pembelajaran PBL yang didapat dari lembar pengamatan keterlaksanaan model pembelajaran PBL serta tes keterampilan berpikir kritis.

Hasil dari lembar pengamatan keterlaksanaan model pembelajaran PBL dan tes keetampilan berpikir kritis akan dianalisis secara deskriptif kuantitatif. Tes keterampilan berpikir kritis dilaksanakan sebanyak dua kali, terdiri dari pre-test yang dilakukan sebelum diberi perlakuan berupa penerapan model pembelajaran PBL dan post-test yang dilakukan sesudah diberi perlakuan berupa penerapan model pembelajaran PBL. Hasil pencapaian keterampilan berpikir kritis akan dianalisis menggunakan uji normalitas, uji homogenitas, uji t-berpasangan, dan analisis $n$-gain.

Dari analisis $n$-gain akan diketahui kategori peningkatan keterampilan berpikir kritis peserta didik. Kategori dalam analisisi n-gain dapat dilihat pada Tabel 3 berikut.

Tabel 3. Kategori Nilai Gain yang Dinormalkan

\begin{tabular}{cc}
\hline$\left\langle\boldsymbol{g}_{n}\right\rangle$ & Kategori \\
\hline$\left\langle g_{n}\right\rangle \geq 0,7$ & Tinggi \\
$0,7\rangle\left\langle g_{n}\right\rangle \geq 0,3$ & Sedang \\
$\left\langle g_{n}\right\rangle<0,3$ & Rendah \\
\hline
\end{tabular}

(Hake, 1999)

Sedangkan untuk mengetahui kategori keterlaksanaan pembelajaran dapat dilihat pada Tabel 4 berikut,

Tabel 4. Kategori Keterlaksanaan Pembelajaran

\begin{tabular}{cc}
\hline Presentase Rata-Rata & Kategori \\
\hline $0 \%-20 \%$ & Sangat Kurang \\
$21 \%-40 \%$ & Kurang \\
$41 \%-60 \%$ & Sedang \\
$61 \%-80 \%$ & Baik \\
$81 \%-100 \%$ & Sangat Baik \\
\hline
\end{tabular}

\section{HASIL DAN PEMBAHASAN}

Penelitian yang dilaksanakan dengan model pembelajaran PBL telah diperoleh hasil peningkatan keterampilan berpikir kritis peserta didik dan keterlaksanaan model pembelajaran PBL. 


\section{Peningkatan Keterampilan Berpikir Kritis Peserta Didik.}

Berdasarkan hasil yang diperoleh dari nilai pre-test dan post-test peserta didik kelas X MIPA 4, pertama dilakukan uji normalitas. Hasil uji normalitas dapat dilihat pada tabel berikut :

Tabel 5. Hasil Uji Normalitas

\begin{tabular}{cccc}
\hline \multirow{2}{*}{ Kelas } & \multirow{2}{*}{$\boldsymbol{x}_{\text {tabel }}^{\mathbf{2}}$} & \multicolumn{2}{c}{$\boldsymbol{x}_{\text {hitung }}^{\mathbf{2}}$} \\
\cline { 3 - 4 } & Pre-test & Post-test \\
\hline X MIPA & 11,3 & 2,6 & 4,3 \\
\hline
\end{tabular}

Hasil dari uji normalitaas di atas menunjukkan bahwa nilai dari $x_{\text {hitung dari Pre-Test maupun Post-Test }}^{2}$ lebih kecil daripada nilai $x_{\text {tabel }}^{2}\left(x_{\text {hitung }}^{2}<x_{\text {tabel }}^{2}\right)$. Hal tersebut berarti $\mathrm{H}_{0}$ diterima atau soal terdistribusi normal di kelas X MIPA 4. Selanjutnya, untuk mengetahui kehomogenan pada sampel, dilakukan uji homogenitas dengan uji Barlett yang ditunjukkan pada Tabel 6 berikut

Tabel 6. Hasil Uji Homogenitas

\begin{tabular}{cccc}
\hline Kelas & $\boldsymbol{X}^{\mathbf{2}}$ tabel & $\boldsymbol{X}^{2}$ hitung & Kesimpulan \\
\hline $\mathrm{X}$ & & & \\
MIPA & 3,84 & 0,62 & $H_{0}$ diterima \\
4 & & & \\
\hline
\end{tabular}

Hasil dari uji homogenitas pada Tabel 6 di atas menunjukkan bahwa $x_{\text {hitung }}^{2}<$ $x_{\text {tabel }}^{2}$, sehingga dapat dinyatakan variabel pada penelitian ini dalam kategori homogen. Selanjutnya, nilai dari Post-Test dan PostTest di uji-t berpasangan guna mengetahui peningkatan keterampilan berpikir kritis peserta didik yang ditunjukkan dalam Tabel 7.

Tabel 7. Uji t-berpasangan

\begin{tabular}{cccc}
\hline Kelas & $\boldsymbol{t}_{\text {tabel }}$ & $\boldsymbol{t}_{\text {hitung }}$ & Kesimpulan \\
\hline $\mathrm{X}$ & 2,032 & 7,473 & $H_{0}$ ditolak \\
MIPA 4 & & & \\
\hline
\end{tabular}

Berdasarkan dari perhitungan melalui uji t-berpasangan didapat nilai $t_{\text {tabel }}$ lebih kecil dari nilai $t_{\text {hitung }}\left(t_{\text {tabel }}<t_{\text {hitung }}\right)$, sehingga dapat diartikan bahwa adanya perbedaan nilai pretest dan post-test secara signifikan sebelum dan sesudah diberi perlakuan dengan penerapan model pembelajaran PBL. Postest dilakukan sesudah perlakuan dengan penerapan model pembelajaran $\mathrm{PBL}$ sedangkan pre-test dilakukan sebelum perlakuan dengan penerapan model pembelajaran PBL.

Kemudian dilakukan analisis n-gain hasil dari pre-test dan post-test. Hal tersebut dilakukan untuk mengetahui kategori peningkatan keterampilan berpikir kritis peserta didik. Hasil perhitungan analisis $n$ gain dapat dilihat pada Tabel 8.

Tabel 8. Hasil Perhitungan Analisis N-Gain

\begin{tabular}{ccc}
\hline Kelas & $(\mathbf{g})$ & Kategori \\
\hline X MIPA 4 & 0,53 & Sedang \\
\hline
\end{tabular}

Hasil perhitungan analisis n-gain pada Tabel 8 menunjukkan bahwa peningkatan keterampilan berpikir kritis pada peserta didik mengalami peningkatan dengan kategori sedang.

Berdasarkan penelitian Fong, hubungan antara keterampilan berpikir kritis peserta didik dengan prestasi peserta didik di sekolah adalah konstan atau sebanding (Fong, 2017). Proses melatih peserta didik mampu berpikir kritis dapat melalui dengan memberi pertanyaan yang terorganisasi. Sehingga dalam proses tersebut peserta didik dapat akan menjawab yang melibatkan mental yang dibutuhkan dalam mencari pemahaman yang lebih mendalam. (Johnson, 2014)

\section{Keterlaksanaan Model Pembelajaran PBL X MIPA 4}

Penelitian yang telah dilakukan di SMAN 1 Gondang pada kelas X MIPA 4 diamati oleh guru mata pelajran Fisika. Pengamatan yang dilakukan yaitu mengenai keterlaksanaan pembelajaran dengan model PBL berdasarkan rubrik penilaian keterlaksanaan pembelajran. Hasil pengamatan keterlaksanaan pembelajaran tersebut dapat dilihat pada Tabel 9. 
Tabel 9. Hasil Pengamatan Keterlaksanaan Pembelajaran PBL

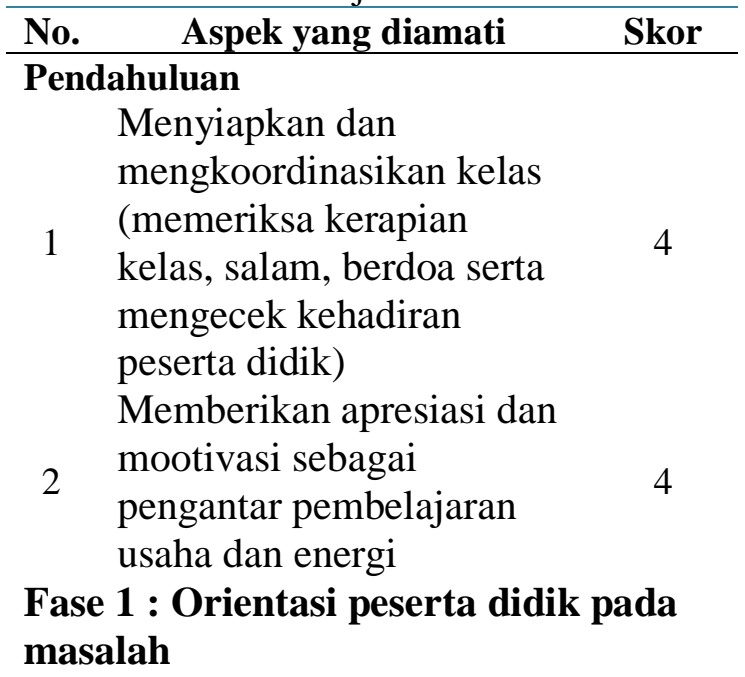
3 Menyampaikan tujuan

Mengorientasi peserta didik terhadap masalah

4 dengan menyajikan video

yang berkaitan dengan usaha dan energi

Fase 2 : Mengorganisasikan peserta didik untuk meneliti

Membimbing peserta didik

5 mengidentifikasi mengenai usaha dan energi yang terkait dalam video.

Fase 3 : Membantu investigasi mandiri maupun kelompok

Membimbing peserta didik

6 dalam menngajukan pertanyaan berdasarkan

apa yang telah diamati.

Fase 4 : Mengembangkan dan menyajikan hasil karya

Membimbing peserta didik

7

mengembangkan hasil

data yang diperoleh dalam

menganalisis.

Fase 5 : Menganalisis dan mengevaluasi proses pemecahan masalah

8 Mengordinasi peserta didik untuk menyampaikan hasil

analisis

Membimbing peserta didik

9 menyimpulkan hasil

4

analisis

\section{Penutup}

Mengevaluasi

10 pembelajaran yang telah 3 dilaksanakan

11 Mengakhiri pembelajaran 4

\section{Suasana Kelas}

12 Guru komunikatif dan 3

13 Managemen waktu dengan 3 tepat

\begin{tabular}{cc}
14 & $\begin{array}{l}\text { Kegiatan pembelajaran } \\
\text { sesuai dengan RPP }\end{array}$ \\
\hline Jumlah & 50 \\
\hline Presentasi & $89 \%$ \\
\hline Kategori & $\begin{array}{c}\text { Sangat } \\
\text { Baik }\end{array}$ \\
\hline
\end{tabular}

Berdasarkan Tabel 9 yang berisi mengenai hasil pengamatan keterlaksanaan pembelajaran PBL dapat diketahui bahwa selama proses pembelajaran PBL di kelas $\mathrm{X}$ MIPA 4 terlaksana dengan presentase $89 \%$ yang berarti terlaksana dengan kategori sangat baik. Mulai dari pembuka, kelima fase PBL, penutup hingga suasana kelas.

\section{KESIMPULAN}

Berdasarkan penelitian yang telah dilakukan di SMAN 1 Gondang pada kelas X MIPA 4 dengan materi Usaha dan Energi dapat disimpulkan bahwa dengan menggunakan metode pembelajaran PBL pada pelajaran fisika materi Usaha dan Energi ternyata mampu meningkatkan keterampilan berpikir kritis peserta didik. Pada uji normalitas dapat dikategorikan terdistribusi normal, kemudian pada uji homogenitas dikategorikan homogen. Pada uji t-berpasangan mendapat hasil bahwa adanya perbedaan nilai pre-test dan post-test secara signifikan sebelum dan sesudah diberi perlakuan dengan penerapan model pembelajaran PBL. Pada analisis $n$-gain dikategorikan sedang mampu meningkatkan keterampilan berpikir 
kritis peserta didik. Selain itu berdasarkan pengamatan keterlaksanaan dari model pembelajaran PBL dikategorikan sangat baik. Pembelajaran fisika menggunakan model PBL dapat digunakan guru untuk meningkatkan keterampilan berpikir kritis peserta didik.

\section{DAFTAR PUSTAKA}

Ardeninyansah, \&. R. (2018). Implementation of Problem-Based Learning in Terms of Student Mathematical Creative Thinking. . Institute of Physics, 1-6.

Arends, R. (2012). learning to Teach (Ninth Edition). New York : McGraw-Hill.

Facione, P. A. (2015). Critical Thinking: What It Is and What It Count. California : Measured Reasons LLC.

Fong, C. J. (2017). Thinking Skill and Creativity. A meta-Analysis on Critical Thinking and Cpmunity College Student Achievement, Vol 26: 71-83.

Hake, R. (1999). Analyzing Change/Gain Scores. AREA-D American Education Research Association's Devision.D, Measurement and Reasearch Methodology.

Ibrahim, M. \&. (2000). Pembelajaran Masalah. Surabaya : Unipress.

Johnson, E. B. (2014). CTL Contextual Teaching and Learning. Bandung : Kaifa.

Mergendoller, J. \&. (2015). Gold Standart PBL : Essential Project Design Elements (ICLD). Ho Chi Minh : Ton Duc Thang University, 43-51.
Ramadha, N. d. (2016). Effect of Problem Based Intruction on. Pascasarjana Ilmu Fisika, Universitas Sebelas Maret Surakarta Higher Other Thinking Skill. Prosiding SNFA (Seminar Nasional Fisika dan Aplikasinya), 96-99.

Rusman. (2013). Paradigma Baru Pembelajaran;Sebagai Referensi Bagi Guru/Pendidik Dalam Implementasi Pembelajaran Yang Efektif dan Berkualitas. Jakarta : Kencana.

Santrok, J. (2014). Psikologi Pendidikan Edisi 5 Buku 2 (Terjemaan). Jakarta : Salemba Humanika.

Saxton, B. B. (2012). Assessing Writing the Crirical Thinking Analytic Rubric (CTAR) : Investigating Intra-Rater and Inter-Rater Reliability of A Scoring Mechanism for Critical Thinking Performance Assessment. Assessing Writing.

Sugiyono. (2015). Metode Penelitian Pendidikan Pendekatan Kuantitatif, Kualitatif, dan R\&D. Bandung : Alfabeta.

Trilling, B. \&. (2009). 21si Cntury Skills : Leraning for Life in Our Times. San Francisco : Jossey-Bass.

Ulfatun Hidayani, M. (2017). Pengembangan Modul Berbasis Problem Based Learning (PBL) Untuk Meningkatkan Keterampilan Berpikir Kritis Pada Materi Usaha dan Energi di SMA/MA. Surakarta : Universitas Sebelas Maret, 107-116. 